\title{
Modelling catchment hydrological responses in a Himalayan Lake as a function of changing land use and land cover
}

\author{
Bazigha Badar*, Shakil A Romshoo and M A Khan \\ Department of Geology and Geophysics, University of Kashmir, Srinagar 190 006, India. \\ *Corresponding author.e-mail: badarbazigha@gmail.com
}

In this paper, we evaluate the impact of changing land use/land cover (LULC) on the hydrological processes in Dal lake catchment of Kashmir Himalayas by integrating remote sensing, simulation modelling and extensive field observations. Over the years, various anthropogenic pressures in the lake catchment have significantly altered the land system, impairing, inter-alia, sustained biotic communities and water quality of the lake. The primary objective of this paper was to help a better understanding of the LULC change, its driving forces and the overall impact on the hydrological response patterns. Multi-sensor and multi-temporal satellite data for 1992 and 2005 was used for determining the spatio-temporal dynamics of the lake catchment. Geographic Information System (GIS) based simulation model namely Generalized Watershed Loading Function (GWLF) was used to model the hydrological processes under the LULC conditions. We discuss spatio-temporal variations in LULC and identify factors contributing to these variations and analyze the corresponding impacts of the change on the hydrological processes like runoff, erosion and sedimentation. The simulated results on the hydrological responses reveal that depletion of the vegetation cover in the study area and increase in impervious and bare surface cover due to anthropogenic interventions are the primary reasons for the increased runoff, erosion and sediment discharges in the Dal lake catchment. This study concludes that LULC change in the catchment is a major concern that has disrupted the ecological stability and functioning of the Dal lake ecosystem.

\section{Introduction}

The valley of Kashmir located in the northern Indian Himalayas, is represented by breathtaking lakes, mountains, snow and spring-fed streams, finest meadows and alpine forests. One of the striking features of the Valley is the chain of lakes categorized into glacial, pine-forest and valley lakes based on their origin, altitudinal situation and nature of biota they contain (Zutshi et al. 1972; Kaul 1977; Zutshi and Khan 1978; Pandit 1996, 1999). In Kashmir valley, eutrophication and dwindling of lake ecosystems is a very recent event of the past 10-30 years, coinciding with a marked civilization evolution in the lake drainage basins (Pandit 1998). Since, there has not been much industrial development in the Kashmir valley, the main contributors towards the degradation of these water bodies are land-use changes, unplanned urbanization, increased soil erosion and reckless use of pesticides for agro-horticultural practices in the catchment areas (Badar and Romshoo 2007a, b). Consequently, most of the lakes in the Kashmir valley exhibit eutrophication (Kaul 1979; Khan 2008) characterized by excessive macrophytic vegetation growth, anoxic deep waters, with high nutrient

Keywords. Dal lake; land use/land cover; catchment; hydrology; remote sensing; geoinformatics; hydrology; erosion; GIS. 
concentrations in their waters (Koul et al. 1990; Khan 2000; Jeelani and Shah 2006).

Dal lake, a cradle of Kashmiri civilization has strong linkages with socio-economics of the state of Jammu and Kashmir in India. Since ages, the lake has been a source of livelihood to a large number of people through various activities ranging from tourism, farming and fisheries. With its multi-faceted ecosystem and grandeur, this lake has been a centre of attraction for national and international tourists for centuries. Other than the tourist trade, the lake is considered to be a goldmine for inhabitants as it provides livelihood to thousands of people who draw benefits from it through a series of trade activities ranging from farming to fish production. During the last few decades, anthropogenic interventions in the catchment like unplanned urbanization, deforestation, intensive grazing, stone quarrying, etc. have exerted tremendous pressure on the world famous freshwater ecosystem. Stone quarrying in certain parts of the catchment although banned now has resulted in largely degraded and defaced mountains that have placed a serious threat of soil erosion and landslides. Increased runoff, erosion and subsequent sedimentation in the catchment have resulted in increased turbidly, decreased light penetration, transparency and the depth of lake (AHEC 2000). Contaminants enter the lake through direct point sources, diffuse agricultural sources and diffuse urban sources. With the increase in the tourist influx, a large number of residential buildings, restaurants and hotels have come up along the lake front at an alarming rate. As a result, these activities are suffocating the lake and contaminating its water mass (Solim and Wanganeo 2008). The gradual reclamation of the lake to provide building and vegetable growing land and the increase in the area of floating gardens combined with natural processes reduced the area of open water within the lake area. As per DANIDA (1990), the Dal lake spread over an area of $22 \mathrm{~km}^{2}$ till 1940 . The present investigations reveal that now the open water extent of the lake barely covers $11.5 \mathrm{~km}^{2}$ (Badar and Romshoo 2007a, b). A sizeable (20\%) portion of the lake is covered by floating gardens reducing the open water area to $59 \%$ of the total Dal lake area (Khan 2000).

Hydrological response in the form of runoff is an integrated indicator of catchment conditions and significant changes in the LULC may affect the overall health and function of a catchment, as it modifies and alters many other inter-related processes. It has been observed that the changes in the land cover types in a catchment substantially affect the hydrological response including surface runoff (Thanapakpawin et al. 2007; Hejazi and Moglen 2008; Breuer and Huisman 2009). Such changes in runoff patterns in turn result in severe environmental implications like increased erosion, sedimentation and nutrient loadings which ultimately find their way into the water bodies particularly fresh water ecosystems and disrupt their ecological stability and functioning. Studies suggest that agriculture, grazing, and urban development can significantly increase sediment yields into adjacent waterways (Heathwaite et al. 1990). Modelling has become an important tool for understanding physical and hydrological processes and impacts (Bronstert 1999). Recent developments of decision support systems based on GIS and distributed hydrological models have provided practical and useful tools to achieve this goal (Fohrer et al. 2001). Geospatial models are excellent tools that allow us to predict the hydrological and other land surface processes and phenomena at different spatial and temporal scales (Young et al. 1987; Shamsi 1996; Zollweg et al. 1996; Frankenberger et al. 1999; Olivera and Maidment 1999; Romshoo 2003; Yuksel et al. 2008). Impact of LULC is assessed by comparing model responses to the incorporation of different scenarios of land cover (Mosier et al. 1997).

Various research studies regarding the Kashmir Himalayan lakes have been centered on their hydrochemical and hydrobiological characteristics (Pandit 1998; Jeelani and Shah 2006; Saini et al. 2008). Very few studies, if at all, have dealt with modelling of different catchment scale processes (Badar and Romshoo 2007a, b; Muslim et al. 2008; Romshoo and Muslim 2011). Most of the Dal lake research conducted earlier has been mostly of conventional/routine nature without any serious attempt to model the effect of any catchment scale processes on the health of the Dal lake ecosystem (Amin and Romshoo 2007; Badar and Romshoo 2007a, b).

The major goals of this study have been to determine the LULC change in Dal lake catchment from 1992-2005 and its driving forces, identify the different critical source areas and simulate the hydrological response patterns under the changed land system scenarios.

\section{Study area}

The Dal lake catchment (figure 1) is located in Kashmir Himalayas, India between the geographical coordinates of $34^{\circ} 02^{\prime}-34^{\circ} 13^{\prime} \mathrm{N}$ latitude and $74^{\circ} 50^{\prime}-75^{\circ} 09^{\prime} \mathrm{E}$ longitude. The lake catchment is not only highly diverse but also covers a huge area of $337 \mathrm{~km}^{2}$ which is nearly 18 times more than the lake area. The general relief of the catchment is a basin which comprises the Dal lake situated at an altitude of approximately $1580 \mathrm{~m}$ and a steep 


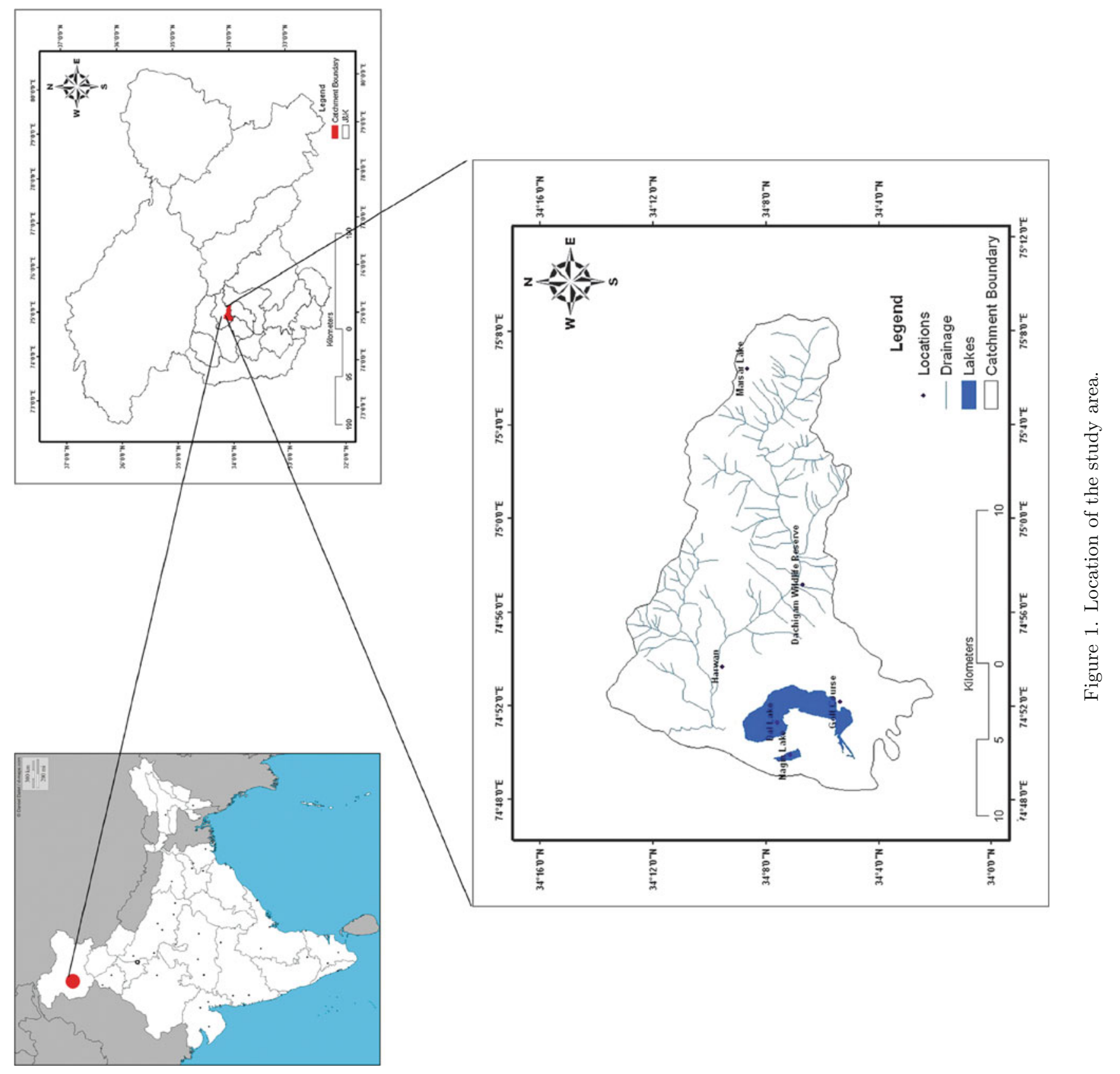


escarpment at an elevation of $4390 \mathrm{~m}$ located along eastern watershed. The flat areas of the catchment are mostly used as cropland, horticulture and builtup where human activities have intensified during the last few decades. The mountainous areas are mostly covered by forest, grassland, scrub lands, and the hilly regions consist of natural vegetation and barren land, respectively. Most of the surface runoff carrying the eroded soil and sediments originate from these mountainous and hilly areas of the catchment. The geological formations of the catchment area are dominated by alluvium, Panjal traps and agglomerate slates (Wadia 1971; Varadan 1977; Data 1983; Bhat 1989).

Dal lake is a shallow, multi-basin lake with inflow and outflow water channels. The drainage pattern in the study area is a combination of trellis and dendritic patterns with the general flow direction being from east to southwest. The lake is fed by a number of underground springs and streams but the main feeding channel is the Dachigam Creek, originating from the Alpine Marsar lake that enters into the lake on the northern side after draining the Dachigam Wildlife Reserve en-route.

The Dal lake catchment belongs to a subMediterranean type climate with four seasons based on mean temperature and precipitation (Bagnolus and Meher-Homji 1959). The catchment receives an average annual rainfall of $650 \mathrm{~mm}$ at Srinagar station and $870 \mathrm{~mm}$ at Dachigam station. March, April and May are the wettest months of the year. The entire Dal Lake catchment remains covered with snow during winter months of December through March with minimum temperatures reeling below zero. The temperature varies between a monthly mean maximum of $31^{\circ} \mathrm{C}$ in July and a minimum of $-4^{\circ} \mathrm{C}$ in January with an average of $11^{\circ} \mathrm{C}$.

\section{Materials and method}

During the present study, a multitude of datasets were used in order to accomplish the research goals. For performing the change detection in land use and land cover, multi-date and multi-sensor satellite data in the form of Landsat Thematic Mapper (TM) and Indian Remote Sensing satellite data [IRS 1D, Linear Imaging Self Scanning (LISS- III)] was used. Landsat TM image of October 1992 with a spatial resolution of $30 \mathrm{~m}$ and band combination of 4:3:2 (IR:R:G) was used in the research that served as reference base map. Similarly, IRSID (LISS-III) of 5 October, 2005 with a spatial resolution of $23.5 \mathrm{~m}$ and spectral resolution of 0.52 $0.86 \mu$ was used in the study (NRSA 2003). Digital Elevation Model (DEM) from Shuttle Radar Topographic Mission (SRTM), with a spatial resolution of 1 arc-sec was used for generating the topographic variables of the catchment for use in the geospatial model (Rodriguez et al. 2006). A soil map of the study area was generated by using remotely sensed classified data aided with extensive laboratory analysis of the soil samples followed by detailed ground truthing. A time series of hydrometeorological data from the nearest observation station was used as input to the geospatial model. Ancillary data related to the sediment loadings was also used in this study.

\subsection{Geospatial modelling approach}

For simulating the hydrological responses under changed land system conditions, a distributed/ lumped parameter watershed model GWLF was used (Haith and Shoemaker 1987). The model simulates runoff, erosion and sediment loads from a watershed given variable-size source areas on a continuous basis and uses daily time steps for weather data and water balance calculations (Haith et al. 1992; Lee et al. 2001; Evans et al. 2008). Monthly calculations are made based on the daily water balance accumulated to monthly values. For the surface loading, the approach adopted is distributed in the sense that it allows multiple LULC scenarios, but each area is assumed to be homogenous with regard to various attributes considered by the model. The model does not spatially distribute the source areas but simply aggregates the loads from each area into a watershed total. For sub-surface loading, the model acts as a lumped parameter model using a water balance approach. The model is particularly useful for application in regions where environmental data of all types is not available to assess the point and non-point source pollution from watershed (Evans et al. 2002; Strobe 2002). The overall schematic flow of the methodology is given in figure 2 .

\subsubsection{Model structure and mechanism}

The GWLF model computes the runoff by using the Soil Conservation Service (SCS) curve number equation. Erosion is computed using the Universal Soil Loss Equation (USLE) and the sediment yield is the product of erosion and sediment delivery ratio (SDR). The yield in any month is proportional to the total transport capacity of daily runoff during the month.

The direct runoff is estimated from daily weather data using SCS curve number equation given by equation (1):

$$
Q_{k t}=\frac{\left(R_{t}+M_{t}-0.2 D S_{k t}\right)^{2}}{R_{t}+M_{t}+0.8 D S_{k t}} .
$$




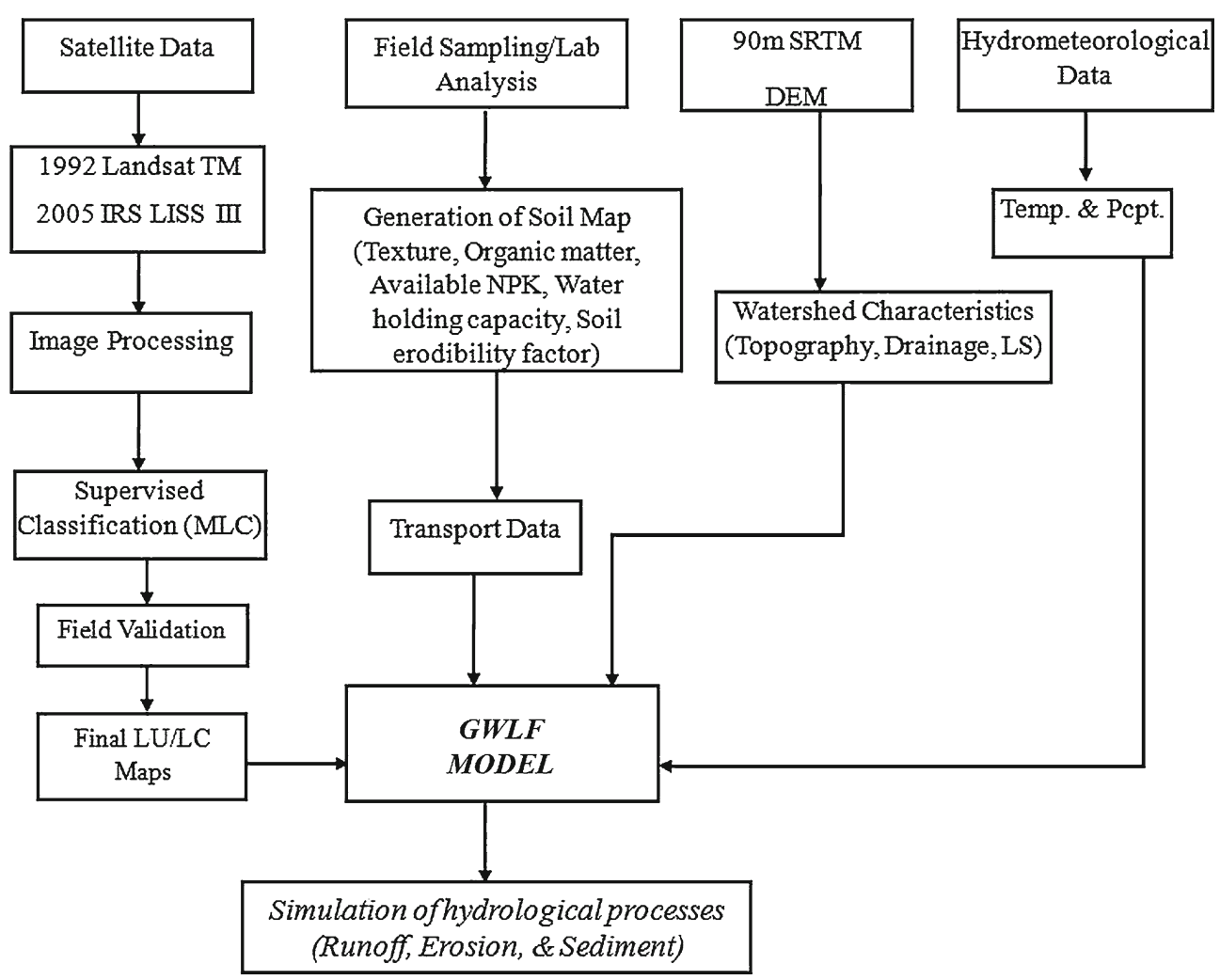

Figure 2. Methodology adopted.

Rainfall $R_{t}(\mathrm{~cm})$ and snowmelt $M_{t}$ (cm of water) on the day $t(\mathrm{~cm})$, are estimated from daily precipitation and temperature data. $D S_{k t}$ is the catchment's storage. Catchment storage is estimated for each source area using $\mathrm{CN}$ values with the equation (2) given below

$$
D S_{k t}=\frac{2540}{C N_{k t}}-25.4
$$

where $C N_{k t}$ is the $\mathrm{CN}$ value for source area $k$, at time $t$.

Stream flow consists of runoff and discharge from groundwater. The latter is obtained from a lumped parameter watershed water balance (Haan 1972). Daily water balances are calculated for unsaturated and shallow saturated zones. Infiltration to the unsaturated and shallow saturated zones equals the excess, if any, of rainfall and snowmelt runoff. Percolation occurs when unsaturated zone water exceeds field capacity. The shallow saturated zone is modelled as linear ground water reservoir. Daily evapotranspiration is given by the product of a cover factor and potential evapotranspiration (Hamon 1961). The latter is estimated as a function of daily light hours, saturated water vapour pressure and daily temperature.

Erosion is computed using the USLE and the sediment yield is the product of erosion and SDR. The yield in any month is proportional to the total capacity of daily runoff during the month.
Erosion from source area $(k)$ at time $t, X_{k t}$ is estimated using the following equation:

$$
X_{k t}=0.132 * R E_{t} * K_{k} *(L S)_{k} * C_{k} * P_{k} * R_{k}
$$

where $K_{k}{ }^{*}(L S)_{k}{ }^{*} C_{k}{ }^{*} P$ are the soil erodibility, topography, cover and management and supporting practice factor as specified by the USLE (Wischmeier and Smith 1978). $R E_{t}$ is the rainfall erosivity on day $t$ (MJ $-\mathrm{mm} / \mathrm{ha}-\mathrm{h}$ ).

Soil loss from stream bank erosion is based upon the familiar sediment transport function having the form

$$
L E R=a Q^{\{0.6\}}
$$

where $L E R$ is the lateral erosion rate in $\mathrm{m} / \mathrm{month}$ which refers to the total distance that soil is eroded away from both banks along the entire length of a stream during a specified period of time, $a$ is an empirically-derived erosion potential factor, and $Q$ is mean monthly stream flow in $\mathrm{m}^{3} / \mathrm{s}$. In this case, the value of 0.6 is used based on a global review of stream bank erosion studies (Van Sickle and Beschta 1983; Lemke 1991; Rutherford 2000).

\subsubsection{Preparation of input data}

A variety of input parameters are required to run the GIS based GWLF model for simulating different hydrological processes at catchment scale which include the land use/land cover data, digital 
topographic data, hydrometeorological data, transport parameter data (hydrologic and sediment) and nutrient parameter data. All these datasets were prepared with the procedures given below.

Land use and land cover data: Land use and land cover data are very important for determining the nature and mechanism of different hydrological responses. For identifying the change that has taken place in the land system and its subsequent effect on the hydrological response patterns in the catchment, multi-date satellite imageries were used. In order to derive the change, supervised classification using maximum likelihood classifier was performed on both the images. This procedure is most often used for the quantitative analysis of remote sensing data and allows the analyst to take charge of the pixel categorization process by specifying to the computer algorithm, the brightness values that will represent one category of land use/land cover in each band of the digital image. Different training sets were developed after analysis of various visual (colour, tone, texture, shape, size, association, convergence of evidence, etc.) and statistical (mean, standard deviation, etc.) characteristics of the data. The training sets were taken from homogeneous cover types as the validity estimate of sample depends upon size and the representativeness of the sample. This was followed by the extensive field verification and ground truthing of the identified land use classes. Accuracy assessment was carried out by using randomly selected points that were collected during the field survey to determine the accuracy of the land use/land cover classification.

Hydrometeorological data: Daily precipitation and temperature data are required for the simulation of hydrological processes by the GWLF model. The daily hydrometeorological data from the India Meteorological Department (IMD) comprising of daily precipitation and daily temperature (minimum and maximum), with a time step of 28 years was prepared as an input to the model. In addition, mean daylight hours for the catchment with latitude $34^{\circ} \mathrm{N}$ were obtained from literature (Haith et al. 1992; Evans et al. 2008). The study area receives an average rainfall of about $650 \mathrm{~mm}$ with most of its precipitation between the months of March and May. January $\left(-0.6^{\circ} \mathrm{C}\right)$ is the coldest month while as July $\left(31.37^{\circ} \mathrm{C}\right)$ is the hottest month. Maximum daylight is recorded for the month of June $(14.3 \mathrm{~h})$ and July $(14.1 \mathrm{~h})$ and the minimum daylight is received in the months of December $(9.7 \mathrm{~h})$ and January $(9.9 \mathrm{~h})$.

Transport parameters: Transport parameters including hydrologic, erosion and sediment of the catchment are those aspects that influence the movement of the runoff and sediments from any given unit in the catchment down to the lake. Transport parameters calculated for different source areas in the catchment are given in table 1 , with the complete procedures for generating each of these are explained as below.

Hydrological parameters: The evapotranspiration (ET) cover coefficient is the ratio of the water lost by evapotranspiration from the ground and plants compared to what would be lost by evaporation from an equal area of standing water (Thuman et al. 2003). The ET cover coefficients depend upon the type of land use and time period within the growing season of a given field crop (FAO 1980; Haith 1987). Typical ET values ranged from 0.3 to 1.00 for plantations depending upon the development stage. Values observed for the bare areas,

Table 1. Transport parameters used for different source areas in GWLF model for Dal Lake catchment.

\begin{tabular}{|c|c|c|c|c|c|c|c|c|c|}
\hline $\begin{array}{l}\text { Source } \\
\text { areas }\end{array}$ & $\begin{array}{l}\text { Hydrological } \\
\text { conditions }\end{array}$ & LS & $\mathrm{C}$ & $\mathrm{P}$ & $\mathrm{K}$ & WCN & WDET & WGET & $\begin{array}{c}\mathrm{ET} \\
\text { coefficient }\end{array}$ \\
\hline Agriculture & Fair & 2.609 & 0.42 & 0.52 & 0.169 & 82 & 0.3 & 1.0 & 0.4 \\
\hline Horticulture & Fair & 3.206 & 0.05 & 0.1 & 0.186 & 87 & 0.3 & 1.0 & 0.6 \\
\hline Forest & Fair & 46.33 & 1 & 1 & 0.226 & 68 & 0.3 & 1.0 & 0.7 \\
\hline Hay/pasture & Fair & 59.38 & 0.03 & 0.74 & 0.255 & 63 & 0.3 & 1.0 & 0.5 \\
\hline Built up & $\mathrm{N} / \mathrm{A}$ & 0.488 & 0.08 & 0.2 & 0.13 & 94 & 1 & 1.0 & 0.1 \\
\hline Bare land & Poor & 42.66 & 0.8 & 0.8 & 0.15 & 89 & 1.0 & 0.3 & 0.1 \\
\hline
\end{tabular}

Note: Good hydrological condition refers to the areas that are protected from grazing and cultivation so that the litter and shrubs cover the soil; fair conditions refer to intermediate conditions, i.e., areas not fully protected from grazing and the poor hydrological conditions refer to areas that are heavily grazed or regularly cultivated so that the litter, wild woody plants and bushes are destroyed.

LS: slope length and steepness factor, C: cover factor, P: management factor, K: soil erodibility value, WCN: weighted curve number values, WDET: weighted average dormant season evapotranspiration, WGET: weighted average growing season evapotranspiration, ET: evapotranspiration coefficient. 
urban surfaces, ploughed lands were 0.1 and 0.4 for agriculture and grasslands.

The SCS curve number is a parameter that determines the amount of precipitation that infiltrates into the ground or enters surface waters as runoff after adjusting it to accommodate the antecedent soil moisture conditions based on total precipitation for the preceding 5 days (EPA 2003a). A combination of factors such as land use/land cover, soil hydrological group, hydrological conditions, soil moisture conditions and management are used to determine the curve numbers (Arhounditsis et al. 2002). In GWLF model, the CN value is used to determine for each land use, the amount of precipitation that is assigned to the unsaturated zone where it may be lost through evapotranspiration and/or percolation to the shallow saturated zone if storage in the unsaturated zone exceeds soil water capacity. In percolation, the shallow saturated zone is considered to be a linear reservoir that discharges to stream or losses to deep seepage, at a rate estimated by the product of zone's moisture storage and a constant rate coefficient (SCS 1986). The soil parameters of the catchment were determined by carrying out a comprehensive analysis of the soil samples in the laboratory. A total of $50 \mathrm{com}-$ posite soil samples, well distributed over various land use and land cover categories were collected from the lake catchment. For the field sampling, similar soil units were delineated using the satellite imagery (Khan and Romshoo 2008). This was followed by laboratory analysis of the samples for parameters like texture, organic matter and water holding capacity. Soil texture was determined by the International Pippeting Method (Piper 1966), field capacity of the samples was determined by Veihmeyer and Hendricjson (1931) and the soil organic matter/organic carbon was determined by the rapid titration method (Walkley and Black 1934). Using the field and lab observations of the soil samples, soil texture was determined using the soil textural triangle (Toogood 1958). The spatial soil texture map (figure 3) and the soil organic matter map (figure 4), were developed by stochastic interpolation method in GIS environment (Burrough 1986). The soil hydrological groups for all the soil units in the catchment were derived from the soil texture and permeability properties (figure 5; table 2).

Sediment yield parameters: Several soil and topographic parameters are required for simulating the soil erosion using the GWLF model. The LS factor used as a combination of slope length and slope steepness parameters determines the effect of topography on soil erosion and was derived from the DEM of the study area (Arhounditsis et al. 2002). The soil erodibility factor (K) of the catchment was generated from the soil texture and soil organic matter content maps were prepared as described above (Steward et al. 1975). The rainfall erosivity factor (RE) was estimated from the product of the storm energy $(E)$ and the maximum

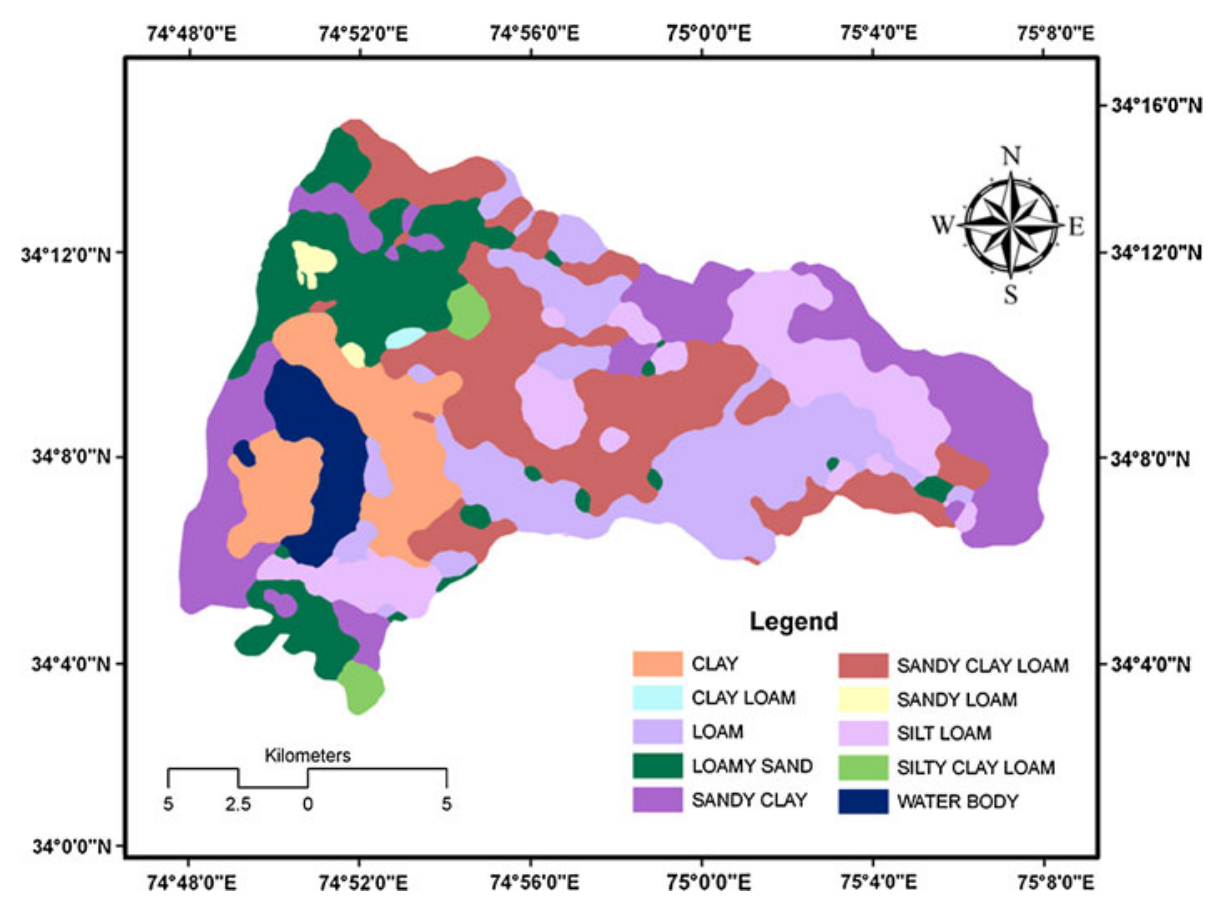

Figure 3. Soil texture map of Dal lake catchment. 


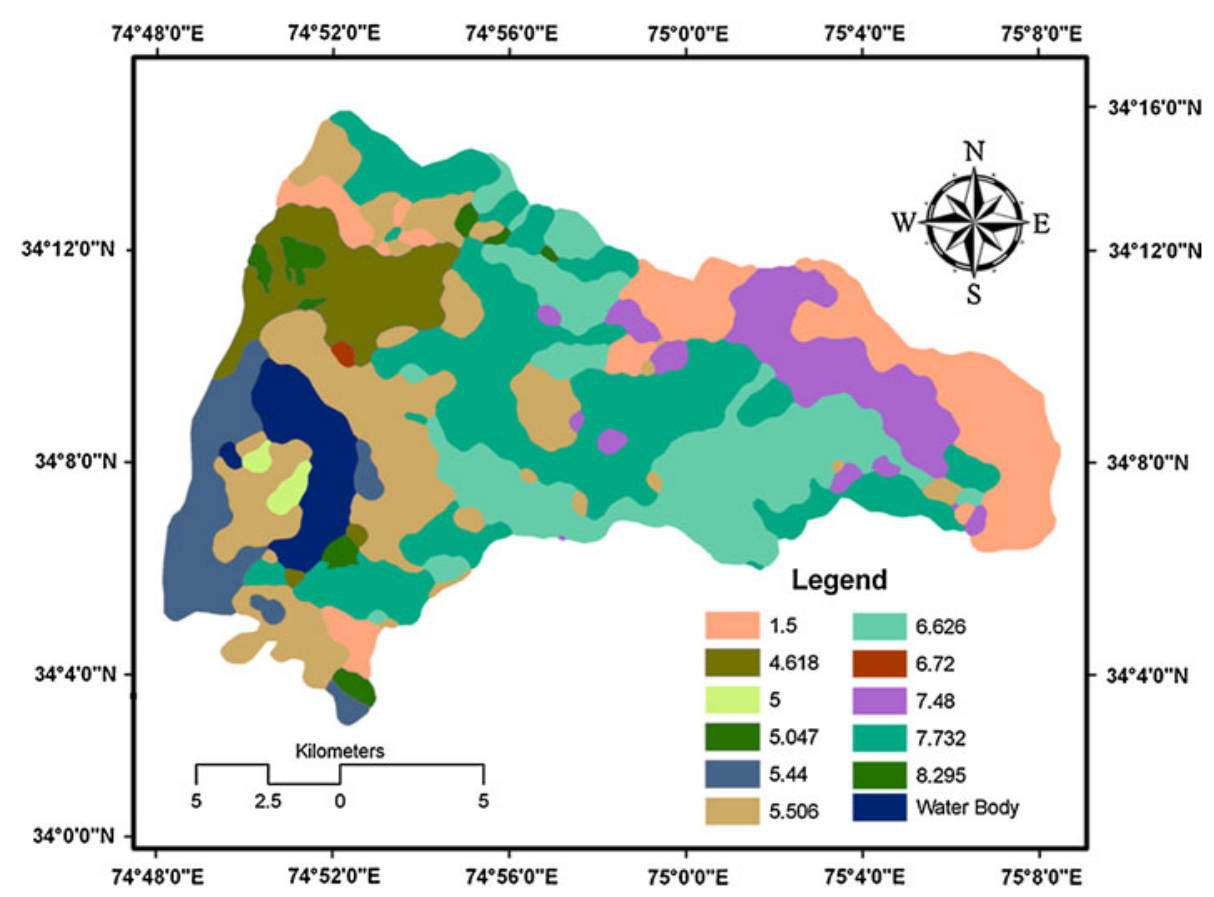

Figure 4. Soil organic matter in Dal lake catchment.

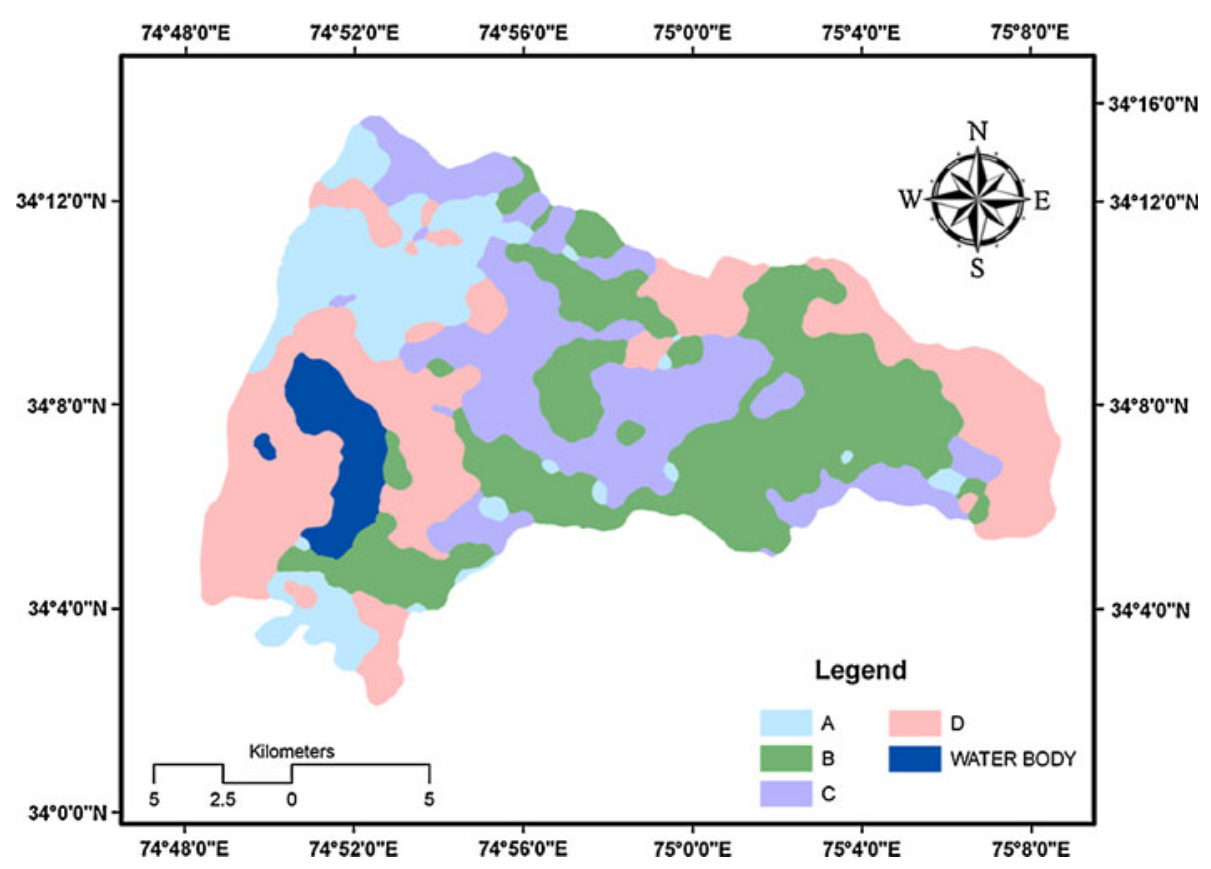

Figure 5. Dominant soil hydrological groups in Dal lake catchment.

30-minute rainfall intensity $\left(\mathrm{I}_{30}\right)$ data collected for that period. Erosivity coefficient for the dry season (May-September) was estimated to be 0.01 and coefficient for wet season was estimated to be 0.034 (Montanarella et al. 2000). The crop management factor $(C)$ related to soil protection cover (Wischmeier and Smith 1978) and the conservation practice factor $(P)$ that reflects soil conservation measures (Pavanelli and Bigi 2004) were determined from the land use and land cover characteristics (Haith et al. 1992; EPA 2003b). The GWLF model estimates the sediment yield by multiplying SDR with the estimated erosion. Use of the logarithmic graph based on the catchment area (Vanoni 1975; Haith et al. 1992; Evans et al. 2008) was made for determining the SDR. 
Table 2. Dominant soil hydrological groups used in the GWLF model.

\begin{tabular}{lcc}
\hline $\begin{array}{l}\text { Dominant } \\
\text { hydrological } \\
\text { group }\end{array}$ & $\begin{array}{c}\text { Soil } \\
\text { texture }\end{array}$ & $\begin{array}{c}\text { Soil runoff potential } \\
\text { and permeability } \\
\text { properties }\end{array}$ \\
\hline A & $\begin{array}{c}\text { Sand, } \\
\text { loamy sand, } \\
\text { sandy loam }\end{array}$ & $\begin{array}{c}\text { Low surface } \\
\text { runoff potential }\end{array}$ \\
B & $\begin{array}{l}\text { Silt loam, } \\
\text { loam }\end{array}$ & $\begin{array}{c}\text { Moderately course soils } \\
\text { with intermediate rates } \\
\text { of water transmission }\end{array}$ \\
& Sandy clay & $\begin{array}{c}\text { Moderately fine texture } \\
\text { soils with slow rates of }\end{array}$ \\
& loam & water transmission \\
& Clay loam, & High surface \\
D & silty clay loam, & runoff potential \\
& sandy clay, & \\
& silty clay, clay & \\
\hline
\end{tabular}

\section{Results}

\subsection{Land use/land cover change detection}

The classification of the satellite imagery for the two study periods provided the spatial distribution of land use/land cover categories. Figures 6 and 7 show the spatial distribution of land use/land cover in 1992 and 2005 respectively, with the statistics and change in area is given in table 3. Both the years were classified into 16 land use/land cover classes namely coniferous forest, deciduous forest, sparse forest, grasslands, scrub lands, plantation, agriculture, horticulture, agriculture fallow, aquatic vegetation, snow, water, water channel area, bare land, bare exposed rocks and built up. However, for the year 2005, an extra class in the form of golf course was identified, as it was not present for the earlier year of 1992. It was observed that for 1992, deciduous forest was the most dominant class in the study area covering $76.49 \mathrm{~km}^{2}$ $(22.69 \%)$ followed by coniferous forest $51.87 \mathrm{~km}^{2}$ (15.39\%), plantation $47.9 \mathrm{~km}^{2}(14.21 \%)$ and grasslands $33.31 \mathrm{~km}^{2}(9.88 \%)$. Snow $1.05 \mathrm{~km}^{2}(0.31 \%)$, aquatic vegetation $1.03 \mathrm{~km}^{2}(0.30 \%)$ and fallow $0.08 \mathrm{~km}^{2}(0.023 \%)$ were the least dominant classes. The statistics for 2005 revealed that the deciduous forest again dominated the land use/land cover area covering $74.69 \mathrm{~km}^{2}$ (22.16\%) followed by coniferous forest $46.2 \mathrm{~km}^{2}(13.70 \%)$, plantation $\mathrm{km}^{2}$ $(10.38 \%)$, grasslands $25.42 \mathrm{~km}^{2}(7.54 \%)$. The least representative of the classes was golf course/turf $0.51 \mathrm{~km}^{2}(0.51 \%)$, water channel area $1.3 \mathrm{~km}^{2}$ $(0.38 \%)$ and fallow $0.004 \mathrm{~km}^{2}(0.001 \%)$.

The change detection from 1992-2005 revealed significant changes in the Dal lake catchment particularly for agriculture, horticulture, built up, bare lands, grasslands, scrub lands and forests. The built up class comprised of the areas of settlements, residential, commercial, industrial establishments and recorded an increase of $12.08 \mathrm{~km}^{2}$ from 1992 2005. Agriculture comprising the cumulative land under different crops decreased by $1.84 \mathrm{~km}^{2}$, while as horticulture that included fruit crops decreased

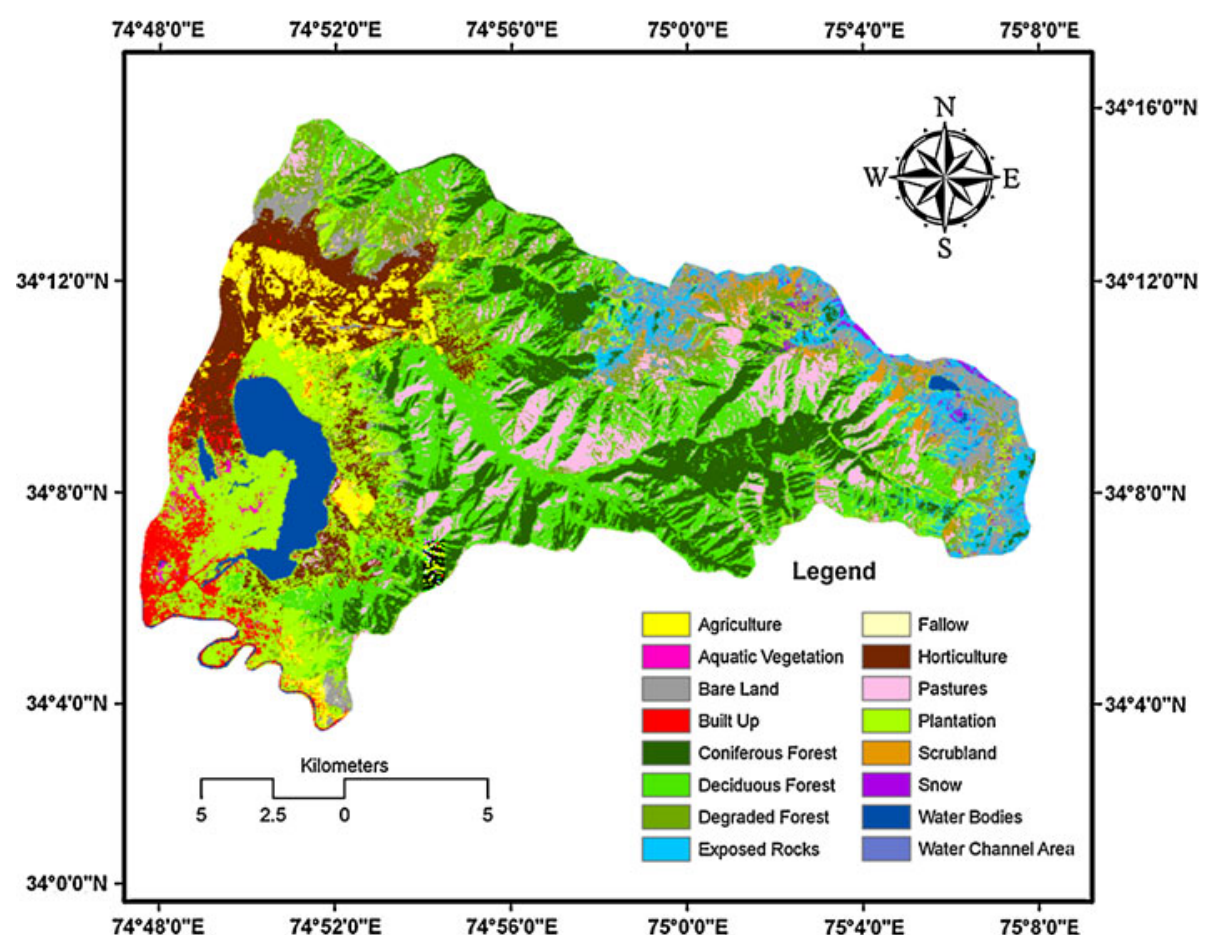

Figure 6. Spatial distribution of land use/land cover for Dal lake catchment in 1992. 


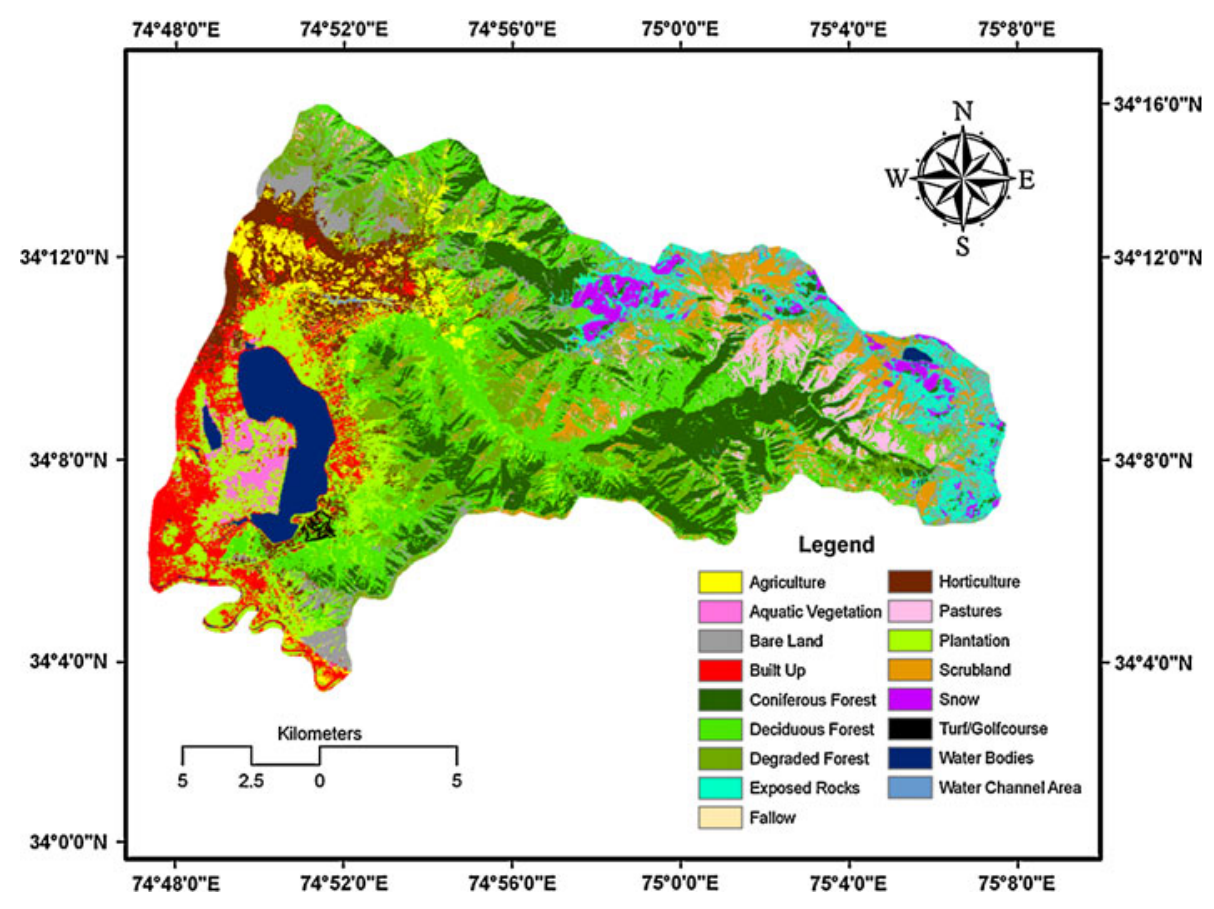

Figure 7. Spatial distribution of land use/land cover for Dal lake catchment in 2005.

Table 3. Change in the land use/land cover pattern of Dal lake catchment (1992-2005).

\begin{tabular}{llcccc}
\hline & & \multicolumn{2}{c}{ Area $\left(\mathrm{km}^{2}\right)$} & Area change \\
\cline { 3 - 4 } Sl. no. & \multicolumn{1}{c}{ Class name } & 1992 & 2005 & $\left(\mathrm{~km}^{2}\right)$ & \% change \\
\hline 1 & Built up & 9.31 & 21.39 & +12.08 & 3.58 \\
2 & Agriculture & 14.71 & 12.87 & -1.84 & 0.54 \\
3 & Agriculture fallow & 0.08 & 0.004 & -0.076 & 0.02 \\
4 & Horticulture & 26.91 & 19.34 & -7.57 & 2.24 \\
5 & Coniferous forest & 51.87 & 46.2 & -5.67 & 1.68 \\
6 & Deciduous forest & 76.49 & 74.69 & -1.8 & 0.53 \\
7 & Sparse forest & 19.76 & 18.8 & -0.96 & 0.28 \\
8 & Grasslands & 33.31 & 25.42 & -7.89 & 2.34 \\
9 & Scrub land & 3.68 & 15.65 & +11.97 & 3.55 \\
10 & Plantation & 47.9 & 35.00 & -12.9 & 3.82 \\
11 & Aquatic vegetation & 1.03 & 4.50 & +3.47 & 1.02 \\
12 & Bare land & 20.82 & 25.26 & +4.44 & 1.31 \\
13 & Bare exposed rocks & 14.09 & 15.7 & +1.61 & 0.47 \\
14 & Water bodies & 14.8 & 13.89 & -0.91 & 0.27 \\
15 & Water channel area & 1.24 & 1.30 & +0.06 & 0.01 \\
16 & Snow & 1.05 & 6.50 & +5.45 & 1.61 \\
17 & Golf course/turf & 0.00 & 0.51 & +0.51 & 15.37 \\
Total & & 337 & 337 & & \\
\hline & & & & &
\end{tabular}

by $7.57 \mathrm{~km}^{2}$. Overall forest cover of the study area showed a declining trend with $5.67 \mathrm{~km}^{2}$, $1.8 \mathrm{~km}^{2}, 0.96 \mathrm{~km}^{2}$ losses in coniferous, deciduous and sparse forest, respectively. Plantation cover also declined by $12.9 \mathrm{~km}^{2}$. Large scale decrease in grassland area $\left(-7.89 \mathrm{~km}^{2}\right)$ and increased scrub lands $\left(+11.97 \mathrm{~km}^{2}\right)$ was also observed during the study. Bare lands included the land parcels devoid of any vegetation cover and increased by $4.44 \mathrm{~km}^{2}$. Other land classes also showed changes, viz., aquatic vegetation $\left(+3.47 \mathrm{~km}^{2}\right)$, bare exposed rocks $\left(+1.61 \mathrm{~km}^{2}\right)$, water bodies $\left(-0.91 \mathrm{~km}^{2}\right)$, water channel area $\left(+0.06 \mathrm{~km}^{2}\right)$, snow $\left(+5.45 \mathrm{~km}^{2}\right)$ and golf course/turf $\left(+0.51 \mathrm{~km}^{2}\right)$.

Table 4 shows the accuracy assessment matrix of the 2005 classified map. The overall accuracy of 
Table 4. Classification accuracy of the land use and land cover of the study area.

\begin{tabular}{|c|c|c|c|c|c|c|}
\hline Class name & $\begin{array}{c}\text { Reference } \\
\text { totals }\end{array}$ & $\begin{array}{c}\text { Classified } \\
\text { totals }\end{array}$ & $\begin{array}{c}\text { Number } \\
\text { correct }\end{array}$ & $\begin{array}{c}\text { Producer's } \\
\text { accuracy }(\%)\end{array}$ & $\begin{array}{c}\text { Users } \\
\text { accuracy }(\%)\end{array}$ & $\begin{array}{c}\text { Kappa } \\
\text { statistics }\end{array}$ \\
\hline Built up & 10 & 9 & 8 & 80 & 88.90 & 0.8851 \\
\hline Agriculture & 5 & 6 & 5 & 100 & 83.33 & 0.8305 \\
\hline Horticulture & 10 & 9 & 9 & 90 & 100.00 & 1 \\
\hline Coniferous forest & 24 & 24 & 22 & 91.67 & 91.67 & 0.9094 \\
\hline Deciduous forest & 32 & 33 & 28 & 87.5 & 84.85 & 0.8304 \\
\hline Sparse forest & 10 & 9 & 8 & 80.00 & 88.89 & 0.8851 \\
\hline Grasslands & 14 & 12 & 12 & 85.71 & 100.00 & 1 \\
\hline Scrub land & 5 & 6 & 5 & 100 & 83.33 & 0.8305 \\
\hline Plantation & 14 & 15 & 12 & 85.71 & 80.00 & 0.7902 \\
\hline Aquatic vegetation & 2 & 3 & 2 & 100 & 66.67 & 0.6644 \\
\hline Barren & 14 & 12 & 11 & 78.57 & 91.67 & 0.9126 \\
\hline Bare exposed rocks & 5 & 6 & 4 & 80.00 & 66.67 & 0.6610 \\
\hline Water & 6 & 6 & 6 & 100.00 & 100.00 & 1 \\
\hline Snow & 2 & 3 & 2 & 100.00 & 66.67 & 0.6644 \\
\hline Total & 300 & 300 & 281 & & & 0.91314 \\
\hline
\end{tabular}

Overall accuracy $=93.67 \%$.

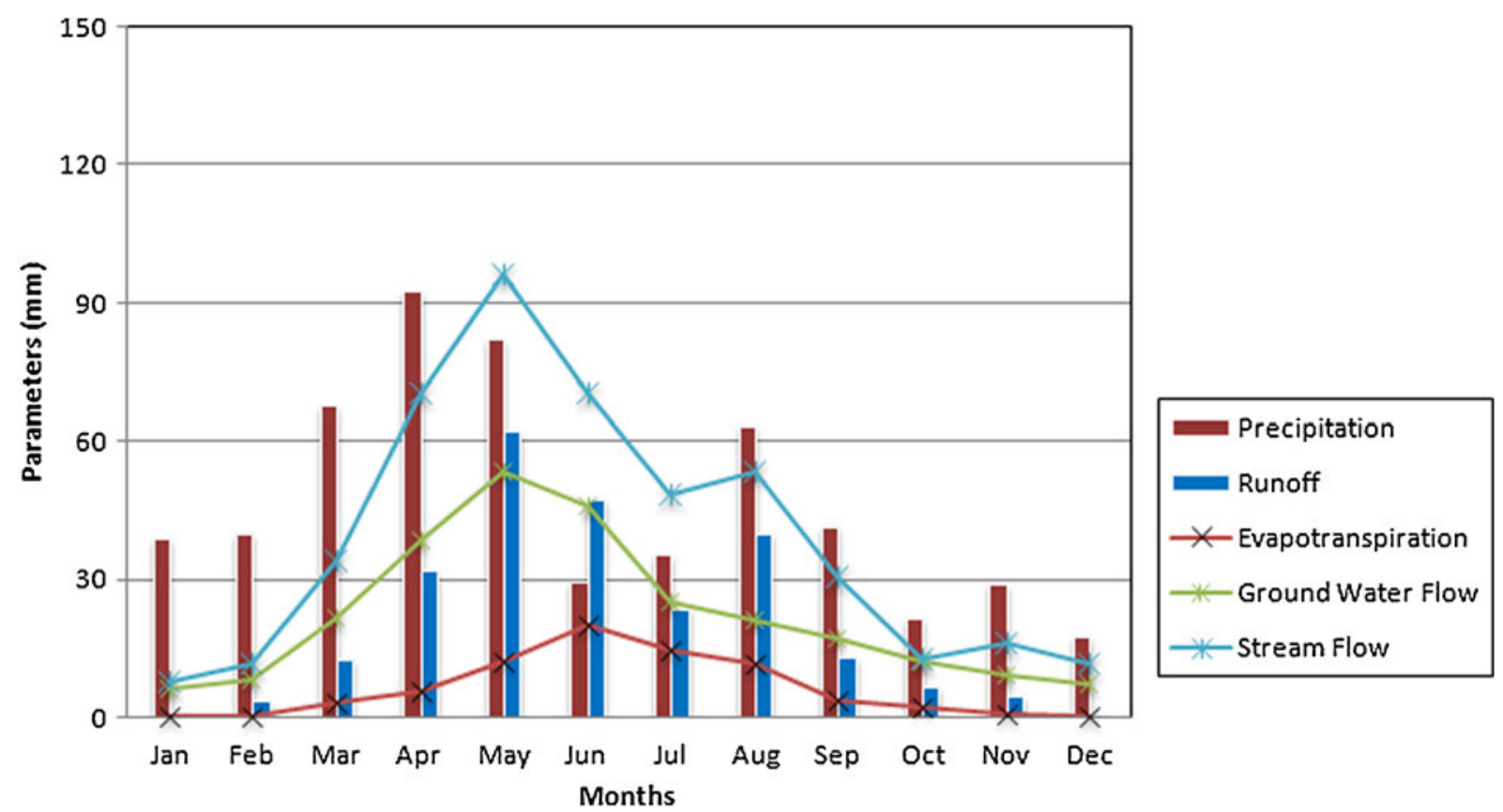

Figure 8. Mean monthly simulated water balance of Dal lake catchment (1981-2008).

the classification was found to be $93 \%$ with overall Kappa statistics equal to 0.91 .

\subsection{Simulated water balance of Dal Lake catchment}

Figure 8 shows the mean monthly simulated water balance of Dal Lake catchment for 28 years (19812008). It is evident that October, November and December are the driest months with all the stream flow being made up of base flow. Since the runoff at this time of the year is very small, most of the nutrients and sediment loading reaching the Dal Lake from its catchment are transported through stream flow and sub-surface flow. Further, it is observed that the maximum rainfall is received in the months of March, April and May of a particular year. During this period, surface runoff, stream flow and ground water flow are substantially high and the peak flows for all the parameters occur in the month of May. As a result, it is expected that 
Table 5. Average rainfall-runoff relationships in Dal lake catchment (19812008).

\begin{tabular}{|c|c|c|c|c|c|c|}
\hline \multirow[b]{2}{*}{ Month } & \multicolumn{2}{|c|}{$\begin{array}{l}\text { Precipitation } \\
\text { total }(\mathrm{mm})\end{array}$} & \multirow{2}{*}{$\begin{array}{c}\begin{array}{c}\text { Precipitation } \\
\text { average }(\mathrm{mm})\end{array} \\
\frac{1992-2005}{}\end{array}$} & \multicolumn{2}{|c|}{$\begin{array}{l}\text { Runoff } \\
\text { (mm) }\end{array}$} & \multirow{2}{*}{$\begin{array}{c}\text { Change } \\
(\mathrm{mm})\end{array}$} \\
\hline & 1992 & 2005 & & 1992 & 2005 & \\
\hline January & 92 & 86 & 39.24 & 2.28 & 3 & 0.72 \\
\hline February & 37 & 189 & 40.15 & 6.05 & 7.02 & 0.97 \\
\hline March & 206 & 105 & 68 & 19.47 & 21.05 & 1.5 \\
\hline April & 89 & 48 & 92.57 & 44.97 & 46.82 & 1.85 \\
\hline May & 91 & 64 & 82.12 & 60.95 & 62.45 & 1.58 \\
\hline June & 39 & 8 & 29.78 & 59.38 & 60.86 & 1.48 \\
\hline July & 53 & 115 & 35.58 & 29.25 & 30.76 & 1.51 \\
\hline August & 72 & 16 & 63.51 & 50.34 & 51.44 & 1.1 \\
\hline September & 116 & 17 & 41.56 & 17.19 & 17.94 & 0.75 \\
\hline October & 21 & 19 & 21.82 & 9.59 & 9.93 & 0.34 \\
\hline November & 18 & 14 & 28.86 & 7.71 & 8.02 & 0.31 \\
\hline December & 47 & 0 & 17.47 & 1.89 & 2.04 & 0.15 \\
\hline Total & 881 & 681 & 560.66 & 309.07 & 321.33 & 12.26 \\
\hline
\end{tabular}

Table 6. Source area contributions to the runoff under changed land use/land cover scenarios.

\begin{tabular}{llcr}
\hline & \multicolumn{2}{c}{ Runoff $(\mathrm{mm})$} & Change \\
\cline { 2 - 3 } Class names & 1992 & 2005 & $(\mathrm{~mm})$ \\
\hline Pasture/scrub land & 203.9 & 219.98 & 16.08 \\
Forest & 181.67 & 188.86 & 7.19 \\
Agriculture & 363.93 & 373.95 & 10.02 \\
Horticulture & 252.94 & 256.79 & 3.85 \\
Bare land & 409.95 & 422.82 & 12.87 \\
Built up & 441.97 & 465.52 & 23.55 \\
Total & 309.06 & 321.32 & 12.26 \\
\hline
\end{tabular}

the sediment loadings from the catchment to the Dal lake will also reach maximum levels during this time of the year (Johnes 1999).

\subsection{Catchment hydrological simulations}

\subsubsection{Rainfall-runoff patterns}

Table 5 shows the total precipitation for the year 1992 and 2005 and the average rainfall-runoff relationships in Dal lake catchment for 28 years (19812008). It is observed that precipitation shows a decreasing trend while comparing the total amount received for 1992 and 2005. A total of $881 \mathrm{~mm}$ of precipitation was recorded for 1992 whereas, $681 \mathrm{~mm}$ was received in 2005 . The statistics for the average rainfall-runoff relations reveal that out of the $560.66 \mathrm{~mm}$ of average rainfall received annually, $309.07 \mathrm{~mm}$ were lost to runoff under $1992 \mathrm{LU} / \mathrm{LC}$. Under the $2005 \mathrm{LU} / \mathrm{LC}, 321.33 \mathrm{~mm}$ runoff was recorded, thus, showing an increase by $12.26 \mathrm{~mm}$ runoff during the 15 years. It was further observed
Table 7. Contribution of different source areas to erosion and sediment loads under the changed land system.

\begin{tabular}{lrcr}
\hline Class names & $\begin{array}{c}\text { Runoff } \\
(\mathrm{mm})\end{array}$ & $\begin{array}{c}\text { Erosion } \\
\text { (Tons/yr) }\end{array}$ & $\begin{array}{r}\text { Sediment } \\
\text { (Tons/yr) }\end{array}$ \\
\hline Pasture/scrub land & 12.87 & 23.25 & 19.58 \\
Forest & 7.19 & 2.72 & 7.34 \\
Agriculture & 10.02 & 46.14 & 22.99 \\
Horticulture & 3.85 & 0.02 & 0.01 \\
Bare land & 16.08 & 578.9 & 30.61 \\
Built up & 23.55 & 0.27 & 0.02 \\
\hline
\end{tabular}

that under both the LU/LC conditions, the highest runoff was recorded in the month of May, followed by June, whereas, the lowest was recorded in the month of December.

\subsubsection{Source area contributions}

The source area contributions to the runoff generation are given in table 6 which shows that built up, bare land, agriculture and pasture/scrub land areas contributed highest to the runoff with an upward trend from the 1992 values. Built-up contributed the highest with $441.97 \mathrm{~mm}$ runoff under $1992 \mathrm{LU} / \mathrm{LC}$ and $465.52 \mathrm{~mm}$ under 2005 $\mathrm{LU} / \mathrm{LC}$, thus, recording an increase of $23.55 \mathrm{~mm}$. An increase of $16.08 \mathrm{~mm}$ of runoff was observed for scrub lands. Bare lands also contributed significantly under both the LU/LC conditions and recorded an increase by $12.87 \mathrm{~mm}$. Agricultural lands also recorded higher values of runoff with an increase of $10.22 \mathrm{~mm}$. Lowest values were observed for forests and pasture lands during the study period. 
Table 8. Comparison of the model predictions and observations for dissolved solids.

\begin{tabular}{lcc}
\hline & \multicolumn{2}{c}{ Sediment $(\mathrm{mg} / \mathrm{l})$} \\
\cline { 2 - 3 } Year 2007 & Predicted & Observed \\
\hline January & 90 & 84 \\
February & 133.5 & 127 \\
March & 276.3 & 242 \\
April & 280 & 245 \\
May & 341.8 & 333 \\
June & 245.7 & 233 \\
July & 199.1 & 192 \\
August & 179.3 & 177 \\
September & 130.4 & 127 \\
October & 102.3 & 106 \\
November & 132 & 125 \\
December & 85.7 & 72 \\
\hline
\end{tabular}

Natsh-Sutcliffe $\left(R^{2}\right)$ coefficient $=0.91$

Table 7 shows the contribution of different source areas to erosion and sediment loads under the changed land system. It was observed that bare land, agricultural areas and pasture/scrub land are the major contributors to both erosion and sediment loads. Barelands recorded an average annual load of 578.9 tons of erosion and 30.61 tons of sediment followed by agriculture with 46.14 tons of erosion and 22.99 tons of sediment and pasture/scrub lands with 23.25 tons of erosion and 19.58 of sediment, respectively. Forests contributed 2.72 tons of erosion and 7.34 tons of sediment. The least contributors were horticulture and urban classes.

\subsubsection{Validation study}

For the validation of the GWLF model results, sediment data for the Dal lake was compiled from January to December 2007. The main purpose of this part of the study was to statistically evaluate the observed and predicted mean annual sediment loads. The Nash-Sutcliffe statistical measure by ASCE (1993) for hydrological studies was used to assess the correlation, or 'goodness-of-fit', between observed and predicted values for mean annual sediment loads. The observations are given in table 8, depicting very good estimates (coefficient of determination $\left.R^{2}=0.91\right)$ for the sediment loads.

\section{Discussion}

Land use/land cover is one of the most critical sources of information that needs to be assessed for better understanding of different catchment scale processes. The present study on the land use/land cover change analysis in the Dal lake catchment using satellite data for the 15-year time period (1992-2005) revealed significant changes which can be largely attributable to the activities of man as land use/land cover which is among the most evident impacts of human activities on natural resources (Lundqvist 1998). Agriculture and horticulture classes showed a decline by 1.84 and $7.57 \mathrm{~km}^{2}$ respectively in the catchment area mostly because of the increased population in the catchment. Increased population and congestion in the Old Srinagar city have resulted in the conversion of large peripheral areas that were essentially used for agro-horticultural purposes into built up mostly residential areas. As a result, an increase of $12.08 \mathrm{~km}^{2}$ in the built up area was observed during the study period. Accelerated nutrient enrichment of the Dal lake due to incoming effluents from the catchment results in the proficient and luxuriant growth of macrophytes, thereby resulting in an increase of $3.47 \mathrm{~km}^{2}$ in the area of aquatic vegetation (Khan 2000; Solim and Wanganeo 2008). This causes the surface water to remain covered by the decomposed thick mats of such vegetation, hence disrupting the ecological balance of the lake. Large scale decline in grassland area $\left(-7.89 \mathrm{~km}^{2}\right)$ reveals the tremendous pressure on this ecologically and socio-economically important land cover. Biotic interference in and around the Dachigam National Park including clearing of the grasslands at the low altitudes for cultivation, exploitation for medicinal plants has been identified as the main reason for this decline. Several decades of grazing and that too beyond the carrying capacity has resulted in the creation of denuded and semidenuded patches in these grasslands. This observation is similar to those made by Bhat et al. (2002) in relation to the human interfered temperate and Alpine pasturelands of Dachigam National Park. Increase in bare lands $\left(+4.44 \mathrm{~km}^{2}\right)$ at both higher and lower elevations of the Dal lake catchment was observed. It was found that the overgrazed grasslands have paved the way for creation of barren area (Shah and Bhat 2004). Also deforested areas of the Dal lake catchment have resulted in the creation of bare lands that is very much vulnerable to increased erosion and sediment yields as well as increased runoff. Increase in scrub land area during the 15-year study period by $11.97 \mathrm{~km}^{2}$ is another significant change observed in the land use/land cover analysis. This increase in area may be attributed to the dwindling grasslands as well as the sparse forests in the catchment. Decline in the overall forest cover of the study area is mostly attributed to the large scale deforestation, both within the Dachigam National Park as well as 
outside it, particularly along the higher reaches (Bhat et al. 2002).

The type and distribution of land use/land cover substantially affects a number of hydrological processes that have a profound effect on lake ecosystems (Matheussen et al. 2000; Fohrer et al. 2001; Quilbe et al. 2008). The results of model simulations for the hydrological processes showed a significant increase against the changing land use/land cover conditions. The source area contributions to the runoff generation as given in table 6 reveal that built up and bare land contributed highest to the runoff with an upward trend from the 1992 values. This is due to the large scale dwindling of the vegetation and increased impervious surface cover in the catchment that impedes the percolation of incident rainfall into the ground, thereby, resulting in higher runoff flows (Tucker and Bras 1998). Agricultural lands because of their loose soils and non-vegetative nature also recorded higher values of runoff (Stoate et al. 2001; Van Rompaey et al. 2001). Because of their vegetated nature, forests and pasture lands recorded lowest values during the study period (Hansen et al. 2004).

The major contribution to the erosion and sediment loadings were found to be highest for bare lands, agriculture areas and scrub lands as the type of land use in a catchment can affect the soil erodibility and sediment source as well as the amount of sediments generated by soil erosion (Woodward and Foster 1997). Observations during the present study suggest that it is primarily the sparsely vegetated or underpressure land use/land cover classes that are more erodible than the vegetated areas and generate higher runoff. Vegetation changes are often the result of anthropogenic pressures (Rishi 1982; Guerra et al. 1998; Janetos and Justice 2000). Soil erosion potential is increased if the soil has no or very little vegetative cover as is the case with the major contributing classes in this study (Elwell and Stocking 1976; Wischmeier and Smith 1978). Agricultural lands also reported high rates of soil and sediment loss (Dunne et al. 1978; Singh and Prakash 1985; Kilwe 1985). In general, as the protective canopy of land cover increases, the erosion hazard decreases (Snelder and Bryan 1995; Mkhonta 2000), hence, forests contribute less as compared to the other classes and the loads, if any, are mainly from the degraded forests. Stress on vegetation manifested due to biotic interferences such as overgrazing of grasslands beyond the carrying capacity, clearing of forest areas for construction and agricultural purposes has lead to the creation of denuded patches that result in erosion in Dal catchment (Bhat et al. 2002). Moreover, increase in the barren and scrub land areas during the said period has also contributed largely to runoff without much infiltration capacity. As the intensity of land use change increases, infiltration and the ability to recharge ground water decreases, consequently increasing the runoff and leading to increased water pollution and physical damage to aquatic systems (Miller and Mc Cormick 2001). Stone quarring in certain areas of the Dal catchment, although banned now, has resulted in largely degraded and defaced mountains that has placed a serious threat of soil erosion and landslides. The subsequent sediment loss, that is carried through the streams downslope pollutes the waters of Dal lake (Shah and Bhat 2004). The sediment/silt generated from various land use/land cover classes in the catchment finally flows into the lake largely through the Telbal stream and have caused reduction of water depth and water volume and impacted thermal stability of the Dal lake (Zutshi and Yousuf 2000). With the increased sedimentation and silt accumulation, the lake ages, maximum depth lessens and volume of deep water diminishes more strikingly (Kurta and Kira 1990; Deevery 1995).

\subsection{Conservation and management measures}

The results of the current study have established that the Dal lake represents a case of threatened ecosystem in dire need of management with land use/land cover changes and subsequent hydrological changes like increased runoff, erosion and sedimentation in its catchment as the major pressures/threats to its existence. For addressing these issues, implementation of a watershed approach with the incorporation of best management practices (BMPs) is expected to play a major role in restoration of the lake. The BMPS can be implemented to start with the impaired watersheds utilizing both the natural landscape as well as artificial structural options. The best management practices particularly related to the urban and the agriculture areas can be very valuable in controlling/checking the inflow of nutrients and sediments into the lake. Agricultural BMPS such as cover crops, strip/contour farming, terrace farming and grazing land management should be promoted in the catchment keeping in view their efficacy in controlling the erosion and sediment loadings. It is also suggested to use various soil binding plant species like Acacia (Robinia pseudoacacia), Willow (Salix sp.), and Popular (Populus sp.) to help control erosion and soil loss. Urban BMPS such as the detention basins and constructed wetlands can prove to be very effective for the temporary capture and storage of surface runoff during high rainfall events and shall be very useful in checking the amount of sediments and nutrients before the water is released downstream. 


\section{Conclusions}

This study presents the LULC change in the Dal lake catchment of Kashmir Himalayas, its driving forces and the influence it has on various hydrological processes. The results clearly reveal that the changing land system strongly affects the response of hydrological patterns like runoff, erosion and sediment loadings. Increased anthropogenic interventions, unplanned urbanization, deforestation in the catchment were identified as the driving forces that led to the land use/cover change in the catchment. Remotely sensed data coupled with GIS simulation modelling has been observed to have a potential scientific value for the study of humanenvironment interactions, and has, therefore, been identified as a useful tool to aid such processes in case of lake ecosystems. This integrated approach used for this study provided reliable estimates over variable critical source areas in the lake catchment. Built up, bare lands, agriculture and scrub lands were the major critical source areas and contributed the maximum to runoff, erosion and sediment yields. All the studied hydrological parameters recorded higher values during the wet periods as against the drier periods. This revealed that precipitation has a significant influence on such processes and affects their transport from the catchment to the lake inlet. The research methodology established during the present study should help in the effective conservation and management of other threatened lacustrine ecosystems of Kashmir Himalaya.

\section{Acknowledgements}

The authors are thankful to the India Meteorological Department and Division of Agronomy, Shere-Kashmir University of Agricultural Sciences and Technology of Kashmir, Shalimar for providing climatic data for this study.

\section{References}

AHEC 2000 Conservation and Management of Dal-Nigeen Lake; Detailed Project Report submitted to Ministry of Environment and Forests, GOI and Government of Jammu and Kashmir $\mathbf{1 - 5}$.

Amin A and Romshoo S A 2007 Assessing the hydrologic characteristics of Dal lake catchment using GIS; In: Proceedings of TAAL 2007: The 12th World Lake Conference, pp. 659-667.

Arhounditsis G, Giourga C, Loumou A and Koulouri M 2002 Quantitative assessment of agricultural runoff and soil erosion using mathematical modelling: Application in the Mediterranean Region; Environ. Manag. 30(3) $434-453$.
ASCE 1993 Task Committee on definition of criteria for evaluation of watershed models of the watershed management committee, Irrigation and Drainage Division; $J$. Irrig. Drain. Eng. 199(3) 27-30.

Badar B and Romshoo S A 2007a Assessing the pollution load of Dal lake using geospatial tools; In: Proceedings of TAAL 2007: The 12th World Lake Conference, pp. 668679.

Badar B and Romshoo S A 2007b Modelling the non-point source pollution load in an urban watershed using remote sensing and GIS: A case study of Dal lake; J. Himalayan Ecol. Sustain. Dev. 2(1) 21-30.

Bagnolus F and Meher-Homji V M 1959 Bio-climatic types of southeast Asia; Travaux de la Section Scientific at Technique Institut Franscis de Pondicherry, $227 \mathrm{p}$.

Bhat D K 1989 Geology of Karewa basin, Kashmir; Geological Survey of India Records, 122p.

Bhat G A, Qadri M Y and Zutshi D P 2002 An ecological survey of Dachigam National Park, Kashmir with emphasis on grasslands; In: Natural Resources of Western Himalaya (ed.) Pandit A K, Valley Book House, Hazratbal, Srinagar, Kashmir, pp. 341-376.

Bronstert A 1999 Capabilities and limitations of detailed hillslope hydrological modelling; Hydrol. Process. 13(1) 21-48.

Breuer L and Huisman J A 2009 Assessing the impact of land use change on hydrology by ensemble modelling (LUCHEM); Adv. Water Resour. 32 127-128.

Burrough P A 1986 Principles of geographic information systems for land resources assessment; Oxford Press, Oxford.

Data N K 1983 Geology, evolution and hydrocarbon prospectus of Kashmir valley; Petrol. Asia J. 5 176-177.

DANIDA 1990 Supply of deweeding equipment for weed control in Dal Lake, Srinagar, Jammu-Kashmir, India; Appraisal Rep. Proj. Prop. Danish International Development Agency, Copenhagen.

Deevery E S Jr 1995 Life in the depths of pond; Scientific Am. 185(4) 68-72.

Dunne T, Dietrich W E and Bruengo M J 1978 Recent and past erosion rates in semi-arid Kenya; Zeitschrift fur geomorphologie. Supplement Band 29 215-230.

Elwell H A and Stocking M A 1976 Vegetal cover to estimate soil erosion hazard in Rhodesia; Geoderma $\mathbf{1 5}$ $61-70$.

EPA 2003a Modelling report for Wissahickon Creek, Pennsylvania; Siltation TDML Development Final Report, US Environmental Protection Agency, Philadelphia, Pennsylvania.

EPA 2003b Nutrient and sediment TMDAL development for the unnamed tributary to Bush run and upper portions of Bush Run Allegheny and Washington Counties; United States Environmental Protection Agency, Philadelphia.

Evans B M, Lehning D W and Corradini K J 2008 AVGWLF Version 7.1: Users Guide; Penn State Institute of Energy and Environment; The Pennsylvania State University, University Park, PA, USA, 117p.

Evans B M, Lehning D W, Corradini K J, Petersen G W, Nizeyimana E, Hamlett J M, Robillard P D and Day R L 2002 A comprehensive GIS-based modelling approach for predicting nutrient load in a watershed; Spatial Hydrol. 2(2) $1-18$.

FAO 1980 Crop transpiration: Guidelines for computing crop water requirement; Rome, 56p.

Fohrer N, Haverkamp S, Eckhardt K and Frede G G 2001 Hydrologic response to land use changes on the catchment scale; Physics and Chemistry of Earth 26(7-8) $577-582$. 
Frankenberger J R, Brook E S, Walter M T, Walter M F and Steenhuis T S 1999 A GIS-based variable source area hydrology model; Hydrol. Process. 13 805-822.

Guerra F, Puig H and Chaune R 1998 The Forest-Savannah dynamics from multi-data LANDSAT-TM data in Sierra Parima, Venezuela; Int. J. Rem. Sens. 19(11) 2061-2075.

Haan C T 1972 A water yield model for small watersheds; Water Resour. Res. 8(1) 58-69.

Haith D A and Shoemaker L L 1987 Generalized watershed loading functions for stream flow nutrients; Water Resour. Bull. 23(3) 471-478.

Haith D A 1987 Evaluation of daily rainfall erosivity model; Trans. Am. Soc. Agri. Eng. 30(1) 90-93.

Haith D A, Mandel R and Shyan Wu R 1992 Generalized watershed loading function model: Users Manual; Ithaca, New York, USA 14853.

Hamon W R 1961 Estimating potential evapotranspiration; ASCE J. Hydraulics Division 87(HY3) 107-120.

Hansen A J, De Fries R and Turner W 2004 Land use change and biodiversity: A synthesis of rates and consequences during the period of satellite imagery; In: Land change science: Observing, monitoring and understanding trajectories of change on the Earth's surface (eds) Gutman G and Justice C (New York: Springer-Verlag), pp. 277-299.

Heathwaite A L, Burt T P and Trudgill S T 1990 Land-use controls on sediment production in a lowland catchment, southwest England; In: Soil Erosion on Agricultural Land (New York: John Wiley \& Sons), pp. 69-86.

Hejazi M I and Moglen G E 2008 The effects of climate and land use change on flow duration in the Maryland Piedmont region; Hydrol. Process., doi: 10.1002/hyp.7080.

Janetos A C and Justice C O 2000 Land cover global productivity: A measurement strategy for the NASA programme; Int. J. Rem. Sens. 21(6\&7) 1491-1512.

Jeelani G and Shah A Q 2006 Geochemical characteristics of water and sediment from the Dal Lake, Kashmir Himalaya: Constraints on weathering and anthropogenic activity; Environ. Geol. 50(1) 12-23.

Johnes P J 1999 Understanding lake and catchment history as a tool for integrated lake management; Hydrobiologia 396 41-60.

Kaul V 1977 Limnological survey of Kashmir lakes with reference to trophic status and conservation; Int. J. Ecol. Environ. Sci. 3 29-44.

Kaul V 1979 Water characteristics of some fresh water bodies of Kashmir; Current Trends in Life Science 9 221-246.

Khan M A 2000 Anthropogenic eutrophication and red tide outbreak in lacustrine systems of the Kashmir Himalaya; Acta Hydrochem. Hydrobiol. (Weinheim) 28 95-101.

Khan M A 2008 Chemical environment and nutrient fluxes in a flood plain wetland ecosystem, Kashmir Himalayas, India; Indian Forester 134(4) 505-514.

Khan S and Romshoo S A 2008 Integrated analysis of geomorphic, pedologic and remote sensing data for digital soil mapping; J. Himalayan Ecol. Sustain. Dev. 3(1) 39-50.

Kilwe A M 1985 Measurement and prediction of soil erosion in Kiambus and Murang'a Districts of Kenya; National Environmental Secretariat Publication, Nairobi.

Koul V K, Davis W and Zutshi D P 1990 Calcite supersaturation in some subtropical Kashmir Himalayan lakes; Hydrobiologia 192(2-3) 215-222.

Kurta A and Kira T 1990 Water quality impacts; In: Guidelines of Lake Management - Lake Shore Management $\mathbf{3}$ (eds) Jorgensen S E and Offler H L, International Lake Environment Committee Foundation and UNEP, Shinga, Japan, pp. 21-37.
Lee K Y, Fisher T and Rochelle N E 2001 Modelling the hydrochemistry of the Choptank River basin using GWLF and Arc/Info: 2. Model validation and application; Biochemistry 56(3) 311-348.

Lemke K A 1991 Transfer function models of suspended sediment concentrations; Water Resour. Res. 27(3) 293-305.

Lundqvist J 1998 Avert Looming Hydrocide; Ambio 27(6) 428-433.

Matheussen B, Kirschbaum R L, Goodman I A, O'Donnell G M and Lettenmaier D P 2000 Effects of land use change on stream flow in the interior Columbia River Basin (USA and Canada); Hydrol. Process. 14(5) 867-885.

Miller B and Mc Cormick R 2001 The relationship between land use decisions and the impacts on our water and natural resources; Purdue University Cooperative Extension Service, West Lafayette, IN 47907.

Mkhonta M M 2000 Use of remote sensing and Geographic Information System (GIS) in the assessment of soil erosion in the Gwayimane and Mahhuku catchment areas with special attention on soil erodibility (K-Factor); Masters Thesis, International Institute for Geoinformation Science and Earth Observation Enschede, The Netherlands. GISdevelopment $>$ Proceedings $>$ ACRS>2000. www.GISdevelopment.net

Montanarella L, Jones R J A and Knijff J M 2000 Soil erosion risk assessment in Europe; The European Soil Bureau.

Mosier A R, Parton W J, Valentine D W, Ojima D S, Schimel D S and Heinemeyer O $1997 \mathrm{CH}_{4}$ and $\mathrm{N}_{2} \mathrm{O}$ fluxes in the Colorado shortgrass steppe 2. Long-term impact of land use change; Glob. Biogeochem. Cycles 11(1) 29-42.

Muslim M, Romshoo S A and Bhat S A 2008 Modelling the pollution load of Manasbal Lake using remote sensing and GIS; In: Proceedings of the 4th annual symposium of the Indian Society of Geomatics (Geomatica 2008), Bhopal, India, 18-20 February, 2008.

NRSA 2003 National Remote Sensing Agency IRS-P6 data user's handbook; NRSA Report No. IRS-P6/ NRSA/NDC/HB-10/03.

Olivera F and Maidment D R 1999 Geographic Information Systems (GIS)-based spatially distributed model for runoff routing; Water Resour. Res. 35(4) 1155-1164.

Pandit A K 1996 Lakes in Kashmir Himalaya; In: Ecology, Environment and Energy (eds) Abrar H Khan and Ashok K Pandit, University of Kashmir, Srinagar, Jammu and Kashmir, pp. 1-40.

Pandit A K 1998 Trophic evolution of lakes in Kashmir Himalayas: Conservation of lakes in Kashmir Himalayas; In: Natural Resources in Kashmir Himalayas (ed.) Pandit A K, Valley Book House, Srinagar, Kashmir, pp. $178-214$.

Pandit A K 1999 Fresh water ecosystems of the Himalayas; Parthenon Publishing, London, New York.

Pavanelli D and Bigi A 2004 Indirect analysis method to estimate suspended sediment concentration: Reliability and relationship of turbidity and settleable solids; Biosyst. Eng. 3 45-53.

Piper C S 1966 Soil and plant analysis; Hans Publishers, Bombay.

Quilbe R, Rousseau A N, Moquet J S, Savary S, Ricard S and Garbouj M S 2008 Hydrological response of a watershed to historical land use evolution and future land use scenario under climate change conditions; Hydrol. Earth Syst. Sci. 12 101-110.

Rishi V 1982 Ecology of a stream of Doodhganga catchment area (Kashmir Himalayas); Ph.D. Thesis, University of Kashmir.

Rodriguez E, Morris C S and Belz J E 2006 A global assessment of SRTM performance; Photogr. Eng. Rem. Sens. 72 249-260. 
Romshoo S A 2003 Radar remote sensing for monitoring of dynamic ecosystem processes related to the biogeochemical exchanges in tropical peatlands; Visual Geosci. 8 63-82.

Romshoo S A and Muslim M 2011 Geospatial modelling for assessing the nutrient load of a Himalayan lake; Environ. Earth Sci. doi: 10.1007/s12665-011-0944-9.

Rutherford I 2000 Some human impacts on Australian stream channel morphology; In: River Management: The Australasian Experience (eds) Brizga S and Finlayson B, Chicester, John Wiley \& Sons.

Saini R K, Swain S, Patra A, Geelani G, Gupta H, Purushothaman P and Chakrapani G J 2008 Water chemistry of three Himalayan lakes: Dal (Jammu and Kashmir), Khajjiar (Himachal Pradesh) and Nainital (Uttarakhand); Himalayan Geol. 29(1) 63-72.

SCS 1986 Urban hydrology for small watersheds; Soil Conservation Services 55(2) 31.

Shah S A and Bhat G A 2004 Land use pattern in DalDachigam catchment; J. Res. Dev. 4 21-33.

Shamsi U M 1996 Storm-water management implementation through modelling and GIS; J. Water Resour. Plan. Manag. 122(2) 114-127.

Singh G R and Prakash O 1985 Characteristics and erodibility of some hill soils in Uttar Pradesh under varying land use, slope and terracing conditions; J. Indian Soc. Soil Sci. 33 858-864.

Snelder D J and Bryan R B 1995 The use of rainfall simulation tests to assess the influence of vegetation density on soil loss on degraded range lands in the Baringo District, Kenya; Catena 25 105-116.

Solim S and Wanganeo A 2008 Excessive phosphorus loading to Dal Lake, India: Implications for managing shallow eutrophic lakes in urbanized watersheds; Int. Rev. Hydrobiol. 93(2) 148-166.

Steward B A, Woolhiser D A, Wischmeir W H, Carol J H and Frere M H 1975 Control of water pollution from cropland; US Environmental Protection Agency, Washington.

Stoate C, Boatman N D, Borralho R J, Carvalho C R, De Snoo G R and Eden P 2001 Ecological impacts of arable intensification in Europe; J. Environ. Manag. 63 337-365.

Strobe R O 2002 Water quality monitoring network design methodology for the identification of critical sampling points; Ph.D Thesis, Department of Agriculture and Biological Engineering, The Pennsylvania State University, Pennsylvania, 44p.

Thanapakpawin P, Richey J, Thomas D, Rodda S, Campbell B and Logsdon S 2007 Effects of landuse change on the hydrologic regime of the Mae Chaem river basin, NW Thailand; J. Hydrol. 334(1-2) 215-230.

Thuman O E, Andrew and Rees T A 2003 Watershed and water quality modelling, analytical report; Triad Engineering Incorporated, Indianapolis, Indiana 46219.
Toogood J A 1958 A simplified textural classification diagram; Canadian J. Soil Sci. 38 54-55.

Tucker G E and Bras R L 1998 Hill slope processes, drainage density and landscape morphology; Water Resour. Res. 34(10) 2751-2764.

Van Rompaey A J J, Govers G, Van Hecke E and Jacobs K 2001 The impacts of land use policy on the soil erosion risk: A case study in central Belgium; Agri. Ecosyst. Environ. 83 83-94.

Vanoni V A 1975 Sediment Engineering; American Society of Civil Engineers, New York.

Van Sickle J and Beschta R L 1983 Supply-based models of suspended sediment transport in streams; Water Resour. Res. 19(3) 768-778.

Varadan V K S 1977 Geology and mineral resources of the state of India part X Jammu and Kashmir State; Geol. Surv. India 30 1-71.

Veihmeyer F J and Hendricjson A H 1931 The moisture equivalent as a measure of the field capacity of soils; Soil Science 32 181-194.

Wadia D N 1971 Geology of India; Tata McGraw Hill, New Delhi, 344p.

Walkley A and Black C A 1934 An examination of the Degljareff method for determination of soil organic matter and a proposed modification of the Chromic Acid Titration method; Soil Science 37 29-39.

Wischmeier W H and Smith D D 1978 Predicting rainfall erosion losses: A guide to conservation planning; US Department of Agriculture, Washington DC, Agricultural Handbook No. 537.

Woodward J and Foster I 1997 Erosion and suspended sediment transfer in river catchments; Geography 82(4) $353-376$

Young R A, Onstad C A, Bosch D D and Anderson W P 1987 AGNPS, agricultural nonpoint source pollution model: A watershed analysis tool; Conservation Research Report No. 35, U.S. Department of Agriculture, Agricultural Research Service, Washington DC.

Yuksel A, Gundogan R and Akay A E 2008 Using the remote sensing and GIS technology for erosion risk mapping of Kartalkaya Dam Watershed in Kahramanmaras, Turkey; Sensors 8 4851-4865.

Zollweg J A, Gburek W J and Steenhuis T S 1996 SMoRMOD: A GIS integrated rainfall-runoff model; Trans. ASAE 39 1299-1307.

Zutshi D P and Khan M A 1978 On lake typology of Kashmir; In: Environ. Physiol. Ecol. Plants, pp. 465-472.

Zutshi D P and Yousuf A R 2000 Ecology and conservation of Dal Lake; Report prepared for AHEC, University of Roorkee, Roorkee, 105p.

Zutshi D P, Kaul V and Vass K K 1972 Limnological studies of high altitude Kashmir lakes; Verhandlugen der Internationale Vereinigung fur theoretische und Augewandte Limnologie 118 599-604. 